\title{
Effect of Mixing Rotational Speed on Characteristics of Edible Film Containing Tangerine (Citrus reticulate) Essential Oil to Extend the Shelf-Life of Mushroom (Agaricus bisporus)
}

\author{
Youssef M. Riyad ${ }^{1 *}$; Marwa M. Helmy ${ }^{2}$ and Ayat E. Rizk ${ }^{2}$ \\ ${ }^{1}$ Food Science Department, Faculty of Agriculture, Cairo University, Giza, Egypt \\ ${ }^{2}$ Food Technology Research Institute, Agriculture Research Center, Giza, Egypt
}

Received: $17 / 3 / 2020$

\begin{abstract}
Mushrooms are products which lose their unique organoleptic properties after harvesting and, it has a short shelf life. The effect of edible coating of mushroom on shelf life was evaluated by using carrageenan (1.5\%) and different concentrations of tangerine (Citrus reticulate) essential oil (0.2, 0.4 and $0.6 \%$ ). Edible coating solutions were prepared using different rotational speed of mixing $(500,1000$ and $1500 \mathrm{rpm})$. Physiochemical properties of tangerine essential oil and rheological characteristics of edible coating solutions were measured. The results indicated that all edible coating solutions exhibited non-Newtonian pseudoplastic behavior. The highest value of water vapor permeability was for carrageenan (1.5\%) incorporated with tangerine essential oil $(0.2 \%)$ at $500 \mathrm{rpm}$ sample. Essential oil and mixing speed affected the edible film morphology. Edible coating of mushroom affected the weight loss, firmness, moisture content and microbiological properties. The obtained results indicated the possibility of prolonging the period of preserving mushrooms by using the coating film prepared from carrageenan mixed with tangerine essential oil.
\end{abstract}

Keywords: Edible film, mushroom, tangerine essential oil, antioxidant, antimicrobial

\section{INTRODUCTION}

Citrus fruits of the Rutaceae family are extremely wealthy in essential oils. Citrus fruits production is the highest in the world and including species having a place with the "Citrus" genus as lemon (Citrus limon $\mathrm{L}$. Burm. F), orange (Citrus sinensis L. Osbeck), tangerine (Citrus reticulate Blanco) and grapefruit (Citrus paradise Macfie). The essential oils of citrus fruit peels comprised a mixture of many components, e.g. terpenes, and oxygenated compounds. The major component of citrus essential oils is terpenes that reach approximately $47.5 \%$ of the total essential oil. The D-limonene represented a large portion and it has the specific aromatic smell of citrus (Fisher and Phillips, 2006; Bozkurt et al., 2017).

Citrus essential oil (which produced from the peel as a by-product) is an economic and natural alternative as antioxidants. The peels of citrus fruits which are largely discarded as wastes cause environmental problems. The extracted citrus oils from discarded peels can be used as natural food preservatives. Other applications of essential oils are used in microencapsulation incorporating biodegradable polymers, nano-emulsion coatings, spray applications, and antibacterial action mechanisms of the active compounds present in the essential oils (Mahato et al., 2019).

The volatile and non-volatile components of citrus essential oil were 85 to $99 \%$ and 1 to $15 \%$, respectively (Fisher and Phillips, 2008). The active compounds of the essential oils are highly volatile and affected by oxygen, heat and light (Muriel-Galet et al., 2015). The volatile components are monoterpene (such as limonene) and sesquiterpene hydrocarbons and their oxygenated derivatives, including aldehydes, ketones, acids, alcohols, and esters (Mahato et al., 2019).
Coatings are considered as part of the final product by dipping or spraying the surface of food products with a thin layer of coating material. It used to protect food products (Cagri et al., 2004; Cha and Chinnan, 2004). The edible films can be modified vegetable tissue metabolism where affecting respiration; they can be used as a carrier of antimicrobials, antioxidants, vitamins, minerals as well as other preservatives and they can be enriched product formulation. One of the most important roles that the ability of edible coating films to control the transport of moisture, oxygen, aroma, oil, and flavor compounds in food systems, depending on the nature of the edible film-forming materials. The properties of physical and mechanical edible films are of very important due to their influence on product behavior and consumer acceptance (Wiset et al., 2014).

Carrageenan (polysaccharide compounds) can be used for making edible films. It can be obtained from seaweed which is one source of cheap raw materials for making edible films (Saiful et al., 2013).

Saiful et al. (2013) prepared edible film from different concentrations of carrageenan $(1,1.25,1.5$ and $1.75 \%)$ and different concentrations of palm oil as plasticizer $(10,20$ and $30 \%)$. They found that the optimized edible film structure was obtained when using carrageenan with concentrations of 1.25 and $1.5 \%$.

Coating of Manilkara zapota fruits with $1.5 \%$ carrageenan could be prolonged Manilkara zapota shelf-life until 15 days. The use of carrageenan coating was one promising method to improve the stability of Manilkara zapota fruits during storage (Nguyen et al., 2018).

Antimicrobial agents can be incorporated in the edible coating to prevent, or even inhibit the spoilage microorganisms and decrease the risk of pathogenic 
microorganisms on the surface of food, being considered an active packaging. The spoilage of mushroom mechanisms included moisture loss, enzymatic browning and bacterial growth. The rapid respiration rate of mushroom may be shorten its shelflife compared to most ready-to-use vegetables as it has no barrier to protect it from water-loss or from microbial attack (Appendini and Hotchkiss, 2002).

The aim of this work was to study the effect of rotational speed (rpm) of laboratory mixer on the properties of edible coating film made from carrageenan and tangerine (Citrus reticulate) essential oil as an antibacterial coating to extend shelf-life of mushroom.

\section{MATERIALS AND METHODS}

\section{Materials}

Mushrooms (Agaricus bisporus) samples were purchased from a commercial market in Cairo, Egypt, and transported to the laboratory in one hour and selected for uniformity and size. Any bruised or diseased mushroom was removed. Carrageenan and glycerol was purchased from Achmetic Company (India).

\section{Methods}

\section{Extraction of tangerine (Citrus reticulate) essential oil}

The essential oil of tangerine (Citrus reticulate) was extracted by cold press according to ArnouldTaylor et al. (1981).

Physicochemical properties of tangerine (Citrus reticulate) essential oil

Physicochemical properties of tangerine essential oil including specific gravity $\left(20^{\circ} \mathrm{C}\right)$, refractive index (at $20^{\circ} \mathrm{C}$ ), solubility in alcohol $(90 \%)$, acid value and aldehyde content as decanal were determined according to the methods described by Guenther (1948).

\section{DPPH radical scavenging activity}

The antioxidant activity of tangerine essential oil was determined using the free radical 2,2-diphenyl-1picrylhydrazyl (DPPH). Where, the odd electron in the DPPH free radical had a strong absorption maximum at $517 \mathrm{~nm}$. The color turns from purple to yellow as the molar absorptive of the DPPH radical reduced when the odd electron becomes paired with hydrogen from a free radical scavenging antioxidant to form the reduced DPPH-H as mentioned by Choi (2010). The DPPH assay was measured according to the method reported by Brand-Williams et al. (1995). The tangerine essential oil was added by $25,50,100,150,200$ and $250 \mu 1$, compared with ascorbic acid and butylated hydroxyl toluene (BHT), as references (control antioxidants). The radical-scavenging activity was expressed as the percentage quenching of the DPPH radical, and calculated as follows:-

$$
\text { Inhibition of DPPH }(\%)=\frac{A_{\text {blank }}-A_{\text {sample }}}{A_{\text {blank }}} \times 100
$$

Where, A is absorbance

\section{Chemical composition of tangerine (Citrus reticulate) essential oil}

The essential oil of tangerine was analyzed for their components using gas chromatography-mass spectrometry analysis (GC-MS) according to the method outlined by Fan et al. (2018).

\section{Preparation of edible film}

Laboratory mixer (Heidoiph RZR 2020, Germany) was used for mixing the edible film solutions containing tangerine essential oils using different rotational speeds. Coating solutions were prepared by dissolving $1.5 \%$ carrageenan in distilled water with the addition of $0.2,0.4$ and $0.6 \%$ tangerine essential oils, and $1 \%$ glycerol as a plasticizer and three different rotational speeds $(500,1000$ and $1500 \mathrm{rpm})$ were used as shown in Table (1).

Table (1): Experimental samples

\begin{tabular}{ccc}
\hline Sample code & Rotational speed, rpm & Treatments \\
\hline C & ---- & Control (Without edible coating film) \\
T1 & 500 & $1.5 \%$ Carrageenan $+0.2 \%$ tangerine essential oil \\
T2 & 1000 & $1.5 \%$ Carrageenan $+0.2 \%$ tangerine essential oil \\
T3 & 1500 & $1.5 \%$ Carrageenan $+0.2 \%$ tangerine essential oil \\
T4 & 500 & $1.5 \%$ Carrageenan $+0.4 \%$ tangerine essential oil \\
T5 & 1000 & $1.5 \%$ Carrageenan $+0.4 \%$ tangerine essential oil \\
T6 & 1500 & $1.5 \%$ Carrageenan $+0.4 \%$ tangerine essential oil \\
T7 & 500 & $1.5 \%$ Carrageenan $+0.6 \%$ tangerine essential oil \\
T8 & 1000 & $1.5 \%$ Carrageenan $+0.6 \%$ tangerine essential oil \\
T9 & 1500 & $1.5 \%$ Carrageenan $+0.6 \%$ tangerine essential oil \\
\hline
\end{tabular}

\section{Rheological properties}

The rheological properties of the prepared blends were studied to investigate the flow behavior of blends which is an important factor for food coating materials. Rheological parameters (shear stress and shear rate) of carrageenan essential oil blends were measured using Brookfield Engineering labs DV-III Rheometer (USA),
$\mathrm{SC}_{4-21}$ spindle was selected for the measurement according to Brookfield Manual (1998).

\section{Thickness of different edible films}

The thickness of the films was determined using a digital micrometer (MITUTOYO, Model MDC- 25S, resolution $0.001 \mathrm{~mm}, \mathrm{USA}$ ) 


\section{Determination of water vapor permeability (WVP)}

The water vapor transmission rate (WVTR) $\left[\mathrm{g} /\left(\mathrm{s} . \mathrm{m}^{2}\right)\right]$ and water vapor permeability (WVP) through films was determined gravimetrically using the ASTM Method (1996). A circular test cup was used to determine the WVP of the film. The film was first cut into circular shape that was larger than the inner diameter of the cup, the cup was filled with $50 \%$ distilled water and the film was sealed at the top using Paraffin oil, then the cups were placed in a desiccators containing calcium chloride with relative humidity $\mathrm{RH}$ $(0 \%)$ and RH for water $(100 \%)$. The weights of the cups were recorded every hour during 10 hours and two specimens of each film were tested. Linear regression was used to estimate the slope of this line in $\mathrm{g} / \mathrm{h}$. The water vapor transmission rate (WVTR) and water vapor permeability (WVP) were determined using the following equations:

$$
\begin{aligned}
& W V T R=\frac{\Delta m}{\Delta t A} \\
& W V P=W V T R \frac{L}{\Delta R H}
\end{aligned}
$$

Where, $\frac{\Delta m}{\Delta t}$ is the moisture gain weight per time $(\mathrm{g} / \mathrm{s})$, A is the surface area of the film $\mathrm{m}^{2}$, $\mathrm{L}$ is the film thickness $(\mathrm{mm})$ and $\Delta \mathrm{RH}$ is the difference in relative humidity.

\section{Microstructure analysis}

The microstructure of the film was done using scanning electron microscopy (SEM) model (JEOL JSM 5200, Tokyo, JAPAN) according to Shamseldean and Platzer (1989).

\section{Coating application}

\section{Sample preparation and coating treatment}

Mushrooms were selected, based on the pileus size of 30 to $40 \mathrm{~mm}$, no mechanical damage and fungal infection, and refrigerated in darkness at $4^{\circ} \mathrm{C}$. Mushrooms were dipped in the coating solution for 30 sec and the samples were air-dried for $15 \mathrm{~min}$ at room temperature. The coated mushrooms were wrapped in polyethylene stretch film and kept at $4{ }^{\circ} \mathrm{C}$ for a period of 21 days.

\section{Determination of weight loss for mushroom during storage}

Weight-loss for each package was determined according to Henriques et al. (2013)

$$
\text { Weight } \operatorname{loss}(\%)=\frac{W_{o}-W_{f}}{W_{o}} \times 100
$$

Where, $\mathrm{W}_{\mathrm{o}}$ is the original weight on the first day and $\mathrm{W}_{\mathrm{f}}$ is the final weight on the end of storage period.

\section{Mechanical properties (firmness)}

The firmness of coated mushroom samples was conducted by Brookfield Texture Analyzer CT3 using force (N) 10-50 KN (USA) according to AACC (2010).
Moisture contents of different samples of mushrooms

Moisture contents of the fresh and coated mushrooms were determined according to the methods of AOAC (2005).

Microbiological analysis

Assessment of antimicrobial activity of tangerine essential oil

Antimicrobial activity of tangerine essential oil was determined by the disc diffusion method according to Rios and Recio (2005).

\section{Total bacterial count and yeast and mold}

Fresh and coated mushrooms were analyzed for total aerobic plate counts and yeast and molds according to procedures of FDA/BAM (2001).

\section{Statistical analysis}

Means of the results are statistically analyzed using one-way analysis of variance (ANOVA). Where significant differences were observed at 5\% standard deviations (SD). Statistical software (Assistat Version 7.7, Brazil) was used for all statistical analyses according to Silva and Azevedo (2009).

\section{RESULTS AND DISCUSSIONS}

\section{Physicochemical properties of tangerine essential oil}

Physicochemical properties of tangerine essential oil are shown in Table (2). The results showed that specific gravity, refractive index, acid value and aldehyde content as decanal were $0.853,1.4764,0.89$ (mg KOH/g oil) and $2.13(\%)$, respectively. Also, it could be noticed that the essential oil of tangerine was soluble in alcohol (90\%). Javed et al. (2014) reported that the specific gravity and refractive index of tangerine essential oil were 0.86 and 1.465 , respectively. However, Bhuyan et al. (2015) found that the acid value and the aldehyde content of tangerine essential oil were 0.59 and $2.1 \%$, respectively. The slight differences in the results of the refractive index and the acid number of the tangerine essential oil in this study and the previous studies may be due to several factors such as geographical location, season and environmental factors (Bourgou et al., 2012).

Table (2): Physicochemical properties of tangerine essential oil

\begin{tabular}{lc}
\hline Properties & Values \\
\hline Specific gravity & $0.853 \pm 0.09$ \\
Refractive index & $1.4764 \pm 0.10$ \\
Solubility in alcohol (90\%) & Soluble \\
Acid value (mg KOH/g oil) & $0.89 \pm 0.05$ \\
Aldehyde content as decanal (\%) & $2.13 \pm 0.15$ \\
\hline
\end{tabular}

Each value is mean $\pm \mathrm{SD}$ 


\section{Antioxidant activity of tangerine essential oil}

The antioxidant has an important role in reducing the activity of free radicals, by being able to give electron or hydrogen, and then a large percentage of the DPPH radicals will be converted to stable molecules. The antioxidant efficiency is measured by its ability to inhibit the high percentage of free radicals. Therefore, the high values of the DPPH radical scavenging activity indicated the high strong of the material as an antioxidant (Lu and Foo, 2001).

Antioxidant activity values of tangerine essential oil, ascorbic acid and BHT are shown in Table (3). The results indicated that tangerine essential oil has low antioxidant activity when compared with ascorbic acid and BHT for all concentrations studied. The antioxidant activity increased by increasing the concentration of tangerine essential oil. The highest antioxidant activity of tangerine essential oil was $89 \%$ at $250 \mu \mathrm{l} / \mathrm{ml}$. This activity represents approximately $90 \%$ from antioxidant activity of ascorbic acid at $250 \mathrm{ppm}$ and $94 \%$ from antioxidant activity of BHT at $200 \mathrm{ppm}$. These results are in accordance with work of Javed et al. (2014) who reported that tangerine have strong scavenging activity (91.1\%). Correspondingly, Yang et al. (2010) found that citrus peel oil contained limonene which is a major component and having antioxidant activity similar to that of strong antioxidant.

Table (3): DPPH radical scavenging activity (\%) of tangerine essential oil, ascorbic acid and BHT

\begin{tabular}{|c|c|c|c|c|c|c|}
\hline \multirow{3}{*}{ Sample } & \multicolumn{6}{|c|}{ Concentration } \\
\hline & 25 & 50 & 100 & 150 & 200 & 250 \\
\hline & \multicolumn{6}{|c|}{ Radical scavenging activity (\%) } \\
\hline $\begin{array}{l}\text { Tangerine essential } \\
\text { oils }(\mu \mathrm{l} / \mathrm{ml})\end{array}$ & $\begin{array}{l}35.2^{\mathrm{cE}} \\
\pm 0.23\end{array}$ & $\begin{array}{l}51.7^{\mathrm{bD}} \\
\pm 0.75\end{array}$ & $\begin{array}{l}68.0^{\mathrm{bcD}} \\
\pm 0.16\end{array}$ & $\begin{array}{l}71.0^{\mathrm{bC}} \\
\pm 0.23\end{array}$ & $\begin{array}{l}82.0^{\mathrm{bB}} \\
\pm 0.87\end{array}$ & $\begin{array}{l}89.0^{\mathrm{bA}} \\
\pm 0.95\end{array}$ \\
\hline Ascorbic acid (ppm) & $\begin{array}{l}50.2^{\mathrm{aF}} \\
\pm 0.15\end{array}$ & $\begin{array}{l}63.0^{\mathrm{aE}} \\
\pm 0.33\end{array}$ & $\begin{array}{l}77.5^{\mathrm{aD}} \\
\pm 0.67\end{array}$ & $\begin{array}{l}84.1^{\mathrm{aC}} \\
\pm 0.25\end{array}$ & $\begin{array}{l}95.2^{\mathrm{aB}} \\
\pm 0.11\end{array}$ & $\begin{array}{l}98.9^{\mathrm{aA}} \\
\pm 0.12\end{array}$ \\
\hline BHT (ppm) & $\begin{array}{l}47.0^{\mathrm{bE}} \\
\pm 0.13\end{array}$ & $\begin{array}{l}61.1^{\mathrm{abD}} \\
\pm 0.27\end{array}$ & $\begin{array}{l}74.2^{\mathrm{abC}} \\
\pm 0.83\end{array}$ & $\begin{array}{l}85.5^{\mathrm{aB}} \\
\pm 0.75\end{array}$ & $\begin{array}{l}94.3^{\mathrm{aA}} \\
\pm 0.19\end{array}$ & ND \\
\hline
\end{tabular}

-The mean values with different small letter indicate significant differences between columns $(\mathrm{P} \geq 0.05)$

-The mean values with different capital letter indicate significant differences within rows $(\mathrm{P} \geq 0.05)$

- ND: not determined

\section{Chemical profile of tangerine essential oil}

The principal components of tangerine essential oil are presented in Table (4). Nine components were identified representing $100 \%$ of the total oil. The results indicated that D-limonene was the main component $(80.55 \%)$. The other ingredients were in the following order heptadecanoic acid, 10-methyl-, methyl ester (4.95\%), vinyl-2-methoxy-phenol (3.16\%), methoxyphenol $(2.90 \%)$, cytidine $(2.78 \%)$, myrcene $(1.95 \%)$ and vinyl $(1.86 \%)$.

Table (4): Essential oil profile of tangerine

\begin{tabular}{lc}
\hline Components & RA (\%) \\
\hline Myrcene & 1.95 \\
Limonene & 0.54 \\
Vinyl & 1.86 \\
Methoxy-phenol & 2.90 \\
Beta.-Myrcene & 1.31 \\
D-limonene & 80.55 \\
Vinyl-2-Methoxy-Phenol & 3.16 \\
Cytidine & 2.78 \\
Heptadecanoic acid, 10-methyl-, methyl ester & 4.95 \\
\hline Total & $\mathbf{1 0 0}$ \\
\hline RA= peak area relative to the total peak area &
\end{tabular}

Previous studies revealed that there is a great variation between chemical components of citrus peel essential oils and this may be due to several factors such as geographical location, season and environmental factors, in addition to the part of the plant used and the method of extraction (Bourgou et al., 2012). Boudries et al. (2017) found that Citrus reticulate essential oil containing 12 components, representing more than $99 \%$, and limonene was the main component (77.81\%). While, Boughendjioua and Boughendjioua (2017) reported that Citrus reticulate essential oil contained 24 compounds, representing $(95.41 \%)$ of the essential oil and Limonene $(67.04 \%), \gamma$-terpinene $(15.50 \%)$ and $\alpha$ pinene $(2.75 \%)$ were the major components.

\section{Rheological properties of edible coating blends}

Three different rotational speed of mixing were used for the preparation of edible coating blends using carrageenan incorporated with tangerine essential oil. The flow behavior curves (shear rate versus shear stress) of carrageenan $(1.5 \%)$ incorporated with different concentrations of tangerine essential oil $(0.2,0.4$ and $0.6 \%$ ) was plotted as shown in Figure (1). The results showed that all edible coating solutions exhibited nonNewtonian pseudoplastic behavior. Constitutive equations are also important for providing the material parameters required by process control, samples studied obey the following power law relationship:

$$
\tau=k \gamma^{n}
$$

Where, $\tau$ is the shear stress $(\mathrm{Pa}), \mathrm{k}$ is the consistency index, $\gamma$ is the shear rate, $(1 / \mathrm{sec})$, and $n$ is the flow behavior index. 


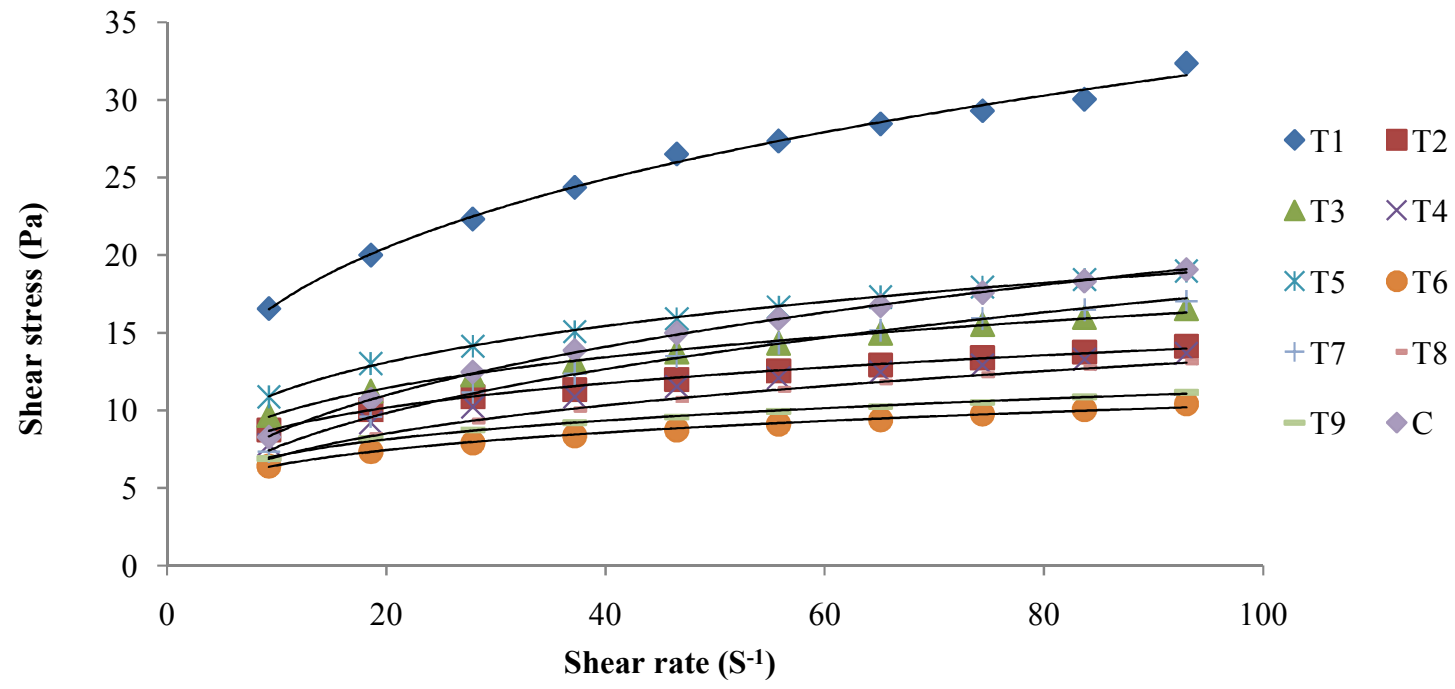

Figure (1): Shear rate - shear stress curves of different edible coating solutions

C: Control (Without edible coating film) - T1, T2 and T3: 1.5\% Carrageenan $+0.2 \%$ tangerine essential oil at 500, 1000 and 1500 $\mathrm{rpm}$, respectively - T4, T5 and T6: 1.5\% Carrageenan $+0.4 \%$ tangerine essential oil at 500, 1000 and $1500 \mathrm{rpm}$, respectively - T7, T8 and T9: $1.5 \%$ Carrageenan $+0.6 \%$ tangerine essential oil at 500, 1000 and $1500 \mathrm{rpm}$, respectively

\section{The thickness of edible film}

Thickness values of the edible film made from carrageenan $(1.5 \%)$ and tangerine essential oil $(0.2,0.4$ and $0.6 \%$ ) are shown in Table (5). The results observed that different mixing rotational speeds and the addition of essential oil affected the thickness of edible films and didn't give a good trend this may be due to intermolecular rearrangement of the matrix components by the incorporation of the essential oil as reported by Pelissari et al. (2009).

The thickness of films decreased with increasing concentration of tangerine essential oil. The highest value of thickness $(0.193 \mathrm{~mm})$ was observed for sample $\mathrm{T} 1$ [ $1.5 \%$ carrageenan $+0.2 \%$ tangerine essential oil] and the lowest value $(0.1 \mathrm{~mm})$ was that of sample T5 [1.5\% Carrageenan $+0.4 \%$ tangerine essential oil].

\section{Water vapor permeability of resultant edible films}

Water vapor permeability (WVP) is an important property for films which are used as edible food coatings because most natural biopolymers are very sustain to water absorption (Pereda et al., 2012). Incorporation of tangerine essential oil at a concentration of $0.2,0.4$ and $0.6 \%$ into carrageenan $(1.5 \%)$ edible film affected the water vapor permeability as shown in Table (5).
The results indicated that WVP decreased with increasing the concentration of tangerine essential oil and increasing mixing rotational speed of mixing, this may be due to the hydrophobic nature of the films where tangerine essential oil had entered the matrix of the films which in turn prevented the water vapor to penetrate through the films (Siah et al., 2018). The highest value of WVP was observed for sample T1 [1.5\% carrageenan $+0.2 \%$ tangerine essential oil $]$ and the lowest value of WVP was observed for sample T5 $[1.5 \%$ carrageenan $+0.4 \%$ tangerine essential oil].

\section{Edible film morphology}

The scanning of electron microscope of edible film made from carrageenan (1.5\%) and tangerine essential oil $(0.4 \%)$ at different mixing rotational speed (500, 1000 and $1500 \mathrm{rpm})$ is shown in Figure (2). The results indicated that control sample (a) $(1.5 \%$ carrageenan) seemed to be flat without pores or cracks. The addition of essential oil to carrageenan changed the microstructure of the edible film and it had more heterogeneous structure as increasing mixing rotational speed from 500 (b) to 1000 (c) rpm, while using 1500 rpm (d) decreased the heterogeneous structure of resultant edible film.

Table (5): Thickness and water vapor permeability (WVP) for carrageenan film incorporated with tangerine essential oil treatments

\begin{tabular}{lccccccccc}
\hline Treatments & T1 & T2 & T3 & T4 & T5 & T6 & T7 & T8 & T9 \\
\hline Thickness (mm) & 0.193 & 0.174 & 0.192 & 0.148 & 0.100 & 0.154 & 0.166 & 0.158 & 0.156 \\
WVTR (g/s.m $\mathbf{m}^{\mathbf{2}}$ & 9.910 & 8.160 & 8.399 & 8.280 & 8.041 & 8.201 & 8.120 & 7.603 & 7.365 \\
WVP $\left(\mathbf{g . m m} / \mathbf{m}^{\mathbf{2}}\right.$.mmHg.day) & 0.020 & 0.014 & 0.016 & 0.012 & 0.008 & 0.012 & 0.013 & 0.012 & 0.011 \\
\hline
\end{tabular}

T1, T2 and T3: 1.5\% Carrageenan $+0.2 \%$ tangerine essential oil at 500, 1000 and $1500 \mathrm{rpm}$, respectively - T4, T5 and T6: $1.5 \%$ Carrageenan $+0.4 \%$ tangerine essential oil at 500, 1000 and $1500 \mathrm{rpm}$, respectively - T7, T8 and T9: $1.5 \%$ Carrageenan $+0.6 \%$ tangerine essential oil at 500,1000 and $1500 \mathrm{rpm}$, respectively 


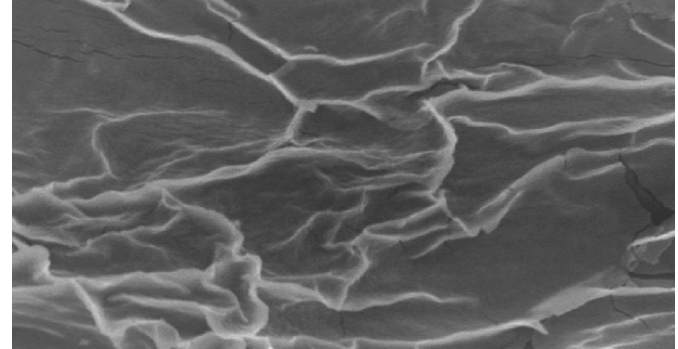

(a)

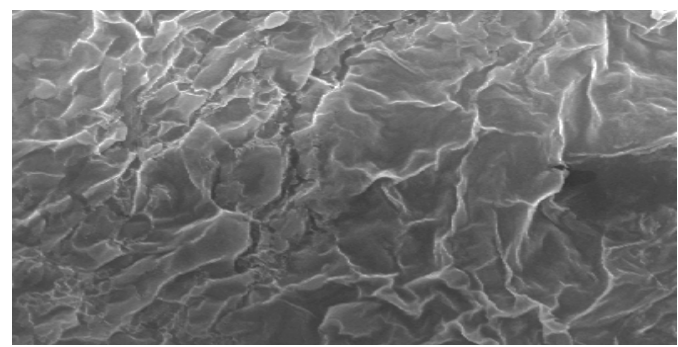

(c)

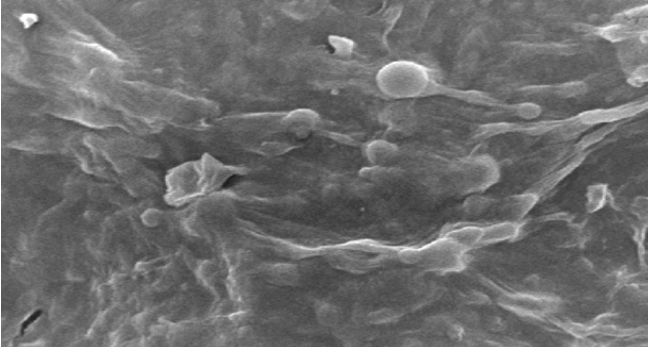

(b)

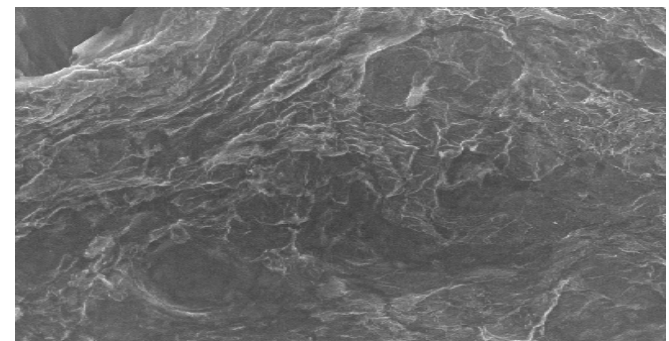

(d)

Figure (2): SEM image of edible film solutions using different mixing rotational speed (magnification of $500 \mathrm{x}$ ): (a) control, (b) $500 \mathrm{rpm}$, (c) $1000 \mathrm{rpm}$ and (d) $1500 \mathrm{rpm}$.

\section{Edible coating of mushroom samples}

\section{Effect of edible coating on weight-loss of mushroom during storage}

Mushrooms are highly perishable products that tended to lose their unique organoleptic properties immediately after harvesting (Jiang et al., 2010). Their short shelf-life is mainly explained by the water loss, high respiration rates and microbial colonization by bacteria or fungi (Mahajan et al., 2008).

Water loss or transpiration is an important physiological process that affected the main quality characteristics of fresh mushrooms, such as weight, appearance and texture (Singh et al., 2010). Figure (3) showed the effect of edible coating using carrageenan $(1.5 \%)$ with different concentrations of tangerine essential oil $(0.2,0.4$ and $0.6 \%)$ on weight loss of mushrooms during storage (18 days) at $4^{\circ} \mathrm{C}$. The results showed that the weight loss of uncoated mushroom (Control, C) was $12.85 \%$, while edible coating reduced weight loss which varied from 0.77 to $4.42 \%$ after 18 days storage. These results could be attributed to the fact that mushrooms were protected by a thin and porous epidermal structure, which does not prevent a quick superficial dehydration, (Ares et al., 2007). It was clearly observed that mushrooms coated samples (T5, T2 and T9) had the lowest weight-loss; this may be due to that edible coating provided a good barrier to moisture and minimized the loss of moisture during storage. It can also act as a gas barrier and slow down the respiration, senescence and enzymatic oxidation (Mohebbi et al., 2012; Ghasemnezhad et al., 2013).

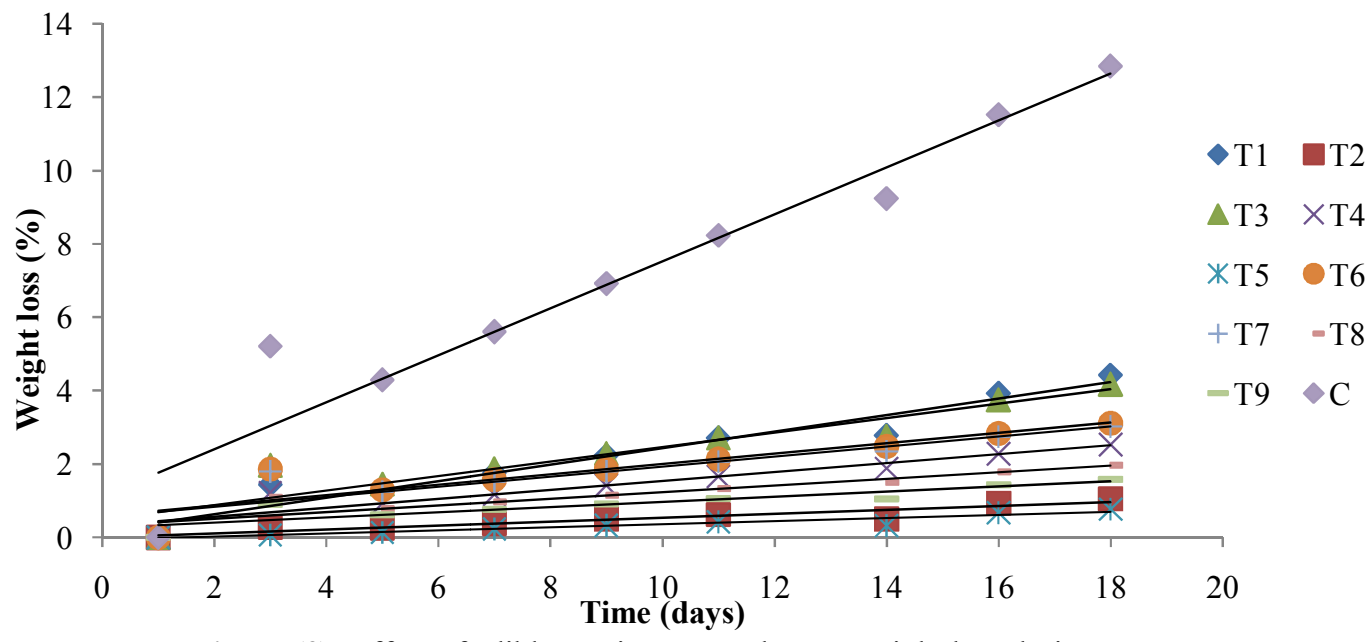

Figure (3): Effect of edible coating on mushroom weight loss during storage

C: Control (Without edible coating film) - T1, T2 and T3: 1.5\% Carrageenan $+0.2 \%$ tangerine essential oil at 500, 1000 and 1500 $\mathrm{rpm}$, respectively $-\mathrm{T} 4$, T5 and T6: 1.5\% Carrageenan $+0.4 \%$ tangerine essential oil at 500, 1000 and $1500 \mathrm{rpm}$, respectively

- T7, T8 and T9: 1.5\% Carrageenan $+0.6 \%$ tangerine essential oil at 500, 1000 and $1500 \mathrm{rpm}$, respectively 


\section{Effect of edible coating on the firmness of mushroom}

Coating plays an important role in the structure maintenance of membrane cell and cell walls in mushroom (Dhall et al., 2013). One of the main changes associated with mushrooms deterioration are changes in their texture. Mushroom softening or loss of firmness during storage has been ascribed to changes in the membrane. These texture changes are also related to protein and polysaccharide degradation, hyphae shrinkage, central vacuole disruption and expansion of intercellular space at the pilei surface (Zivanovic et al., 2000). Figure (4) showed the effect of the edible coating of carrageenan $(1.5 \%)$ with different concentrations of tangerine essential oil $(0.2,0.4$ and $0.6 \%)$ on the firmness of mushroom samples. The results indicated that the uncoated mushroom sample began to collapse after five days and become gradually softer than the coated sample after nine days. However, the coating maintained its firmness for up to 18 days; this may be due to that edible coating directly affects fruit firmness by delaying the ripening process and decreasing the activity of cell wall degrading enzymes (Dang, 2008). It was observed that coated samples of mushrooms had higher firmness and better appearance concerning the control sample. The higher firmness $(23.01 \mathrm{~N})$ was observed for coated sample $\mathrm{T} 5$ and the lowest firmness $(13.94 \mathrm{~N})$ was observed for control sample $(\mathrm{C})$ after 18 days.

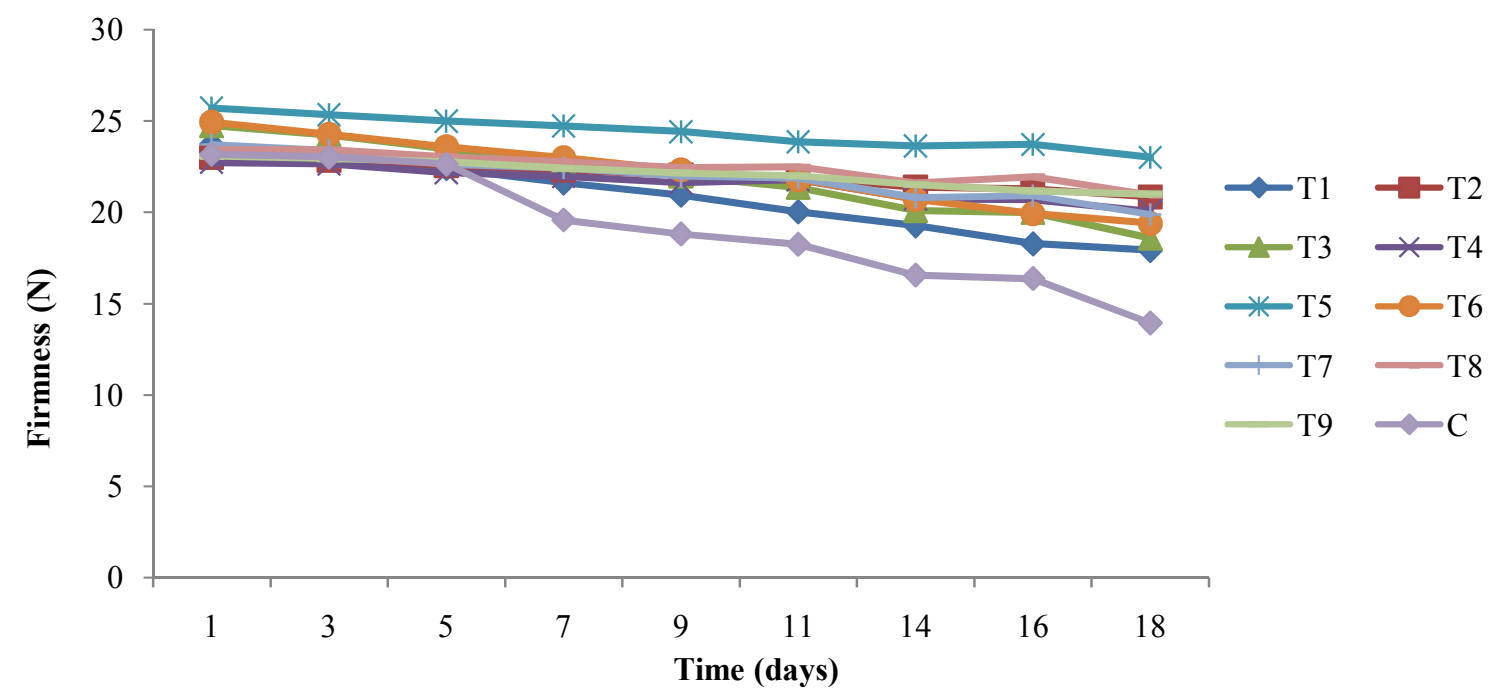

Figure (4): Effect of edible coatings on mushroom firmness

C: Control (Without edible coating film) - T1, T2 and T3: 1.5\% Carrageenan $+0.2 \%$ tangerine essential oil at 500, 1000 and 1500 rpm, respectively - T4, T5 and T6: $1.5 \%$ Carrageenan $+0.4 \%$ tangerine essential oil at 500, 1000 and 1500 rpm, respectively - T7, T8 and T9: 1.5\% Carrageenan $+0.6 \%$ tangerine essential oil at 500, 1000 and $1500 \mathrm{rpm}$, respectively

\section{Moisture contents of mushrooms during storage}

The moisture contents of fresh and coated mushrooms during storage at $4^{\circ} \mathrm{C}$ for 21 days are shown in Table (6). The results indicated that the moisture content of the fresh mushroom was $90.02 \%$ and it ranged between $89-90 \%$ for coated mushroom samples at zero time. Moisture contents reached to approximately $84 \%$ after 21 days. Results also showed that the moisture contents of all treatments reduced after 7 days by about $1.2-2.4 \%$, and it reduced after 14 days by about $4.1-5.4 \%$, meanwhile on day 21 it reduced by about $4.3-7.4 \%$. It could be noticed that no significant differences were observed for reducing moisture contents with increasing mixing rotational speeds, but it was found significant differences with increasing the levels of tangerine essential oil concentrations on the day 21 it could be observed that no significant differences were found between both mushroom coated with carrageenan $(1.5 \%)$ incorporated with 0.2 , and $0.4 \%$ tangerine essential oil using rotational speed of mixing $1000 \mathrm{rpm}$. Also, the results indicated that the lowest moisture content was $83.3 \%$ after 21 days for coated mushrooms with carrageenan (1.5\%) incorporated with $0.2 \%$ tangerine essential oil using rotational speed of mixing $500 \mathrm{rpm}$. The fresh mushrooms did not continue for more than five days, and then it showed signs of deterioration where appeared brown spots and sticky areas, and these signs made the mushrooms unacceptable. The results indicated that the coating of mushrooms with a layer of carrageenan with essential oils of tangerine preserves the moisture content of mushrooms for 21 days at $4{ }^{\circ} \mathrm{C}$ with the beginning of the first signs that made the mushrooms unacceptable after day 18 . These results are in agreement with Brennan et al. (2000) who reported that the most important problem for mushrooms is a postharvest browning severe that reduced the shelf life. Also Singh et al. (2016) reported that mushrooms are extremely sensitive, fast deteriorated within one day after harvest due to high respiratory rate and sensitive skin structure. Thus, the shelf life of the freshly-cut mushrooms is no more than 1-3 days depending on the surrounding environment. Also, they found that the moisture content reduced from 90 to $85.39 \%$ and $85.5 \%$ after three days of the mushrooms preserved at ambient or refrigerated conditions, respectively after washing with plain water and polypropylene used as packaging material. 
Table (6): Moisture contents of fresh and coated mushrooms during storage for 21 days at $4^{\circ} \mathrm{C}$

\begin{tabular}{|c|c|c|c|c|c|c|c|c|c|c|}
\hline \multirow{3}{*}{$\begin{array}{l}\text { Storage } \\
\text { period } \\
\text { (days) }\end{array}$} & \multirow{3}{*}{$\begin{array}{c}\text { Fresh } \\
\text { mushrooms }\end{array}$} & \multicolumn{9}{|c|}{ Moisture contents (\%) } \\
\hline & & \multicolumn{9}{|c|}{ Coated mushrooms treatments } \\
\hline & & T1 & $\mathbf{T 2}$ & T3 & T4 & T5 & T6 & T7 & T8 & T9 \\
\hline $\begin{array}{l}\text { Zero } \\
\text { time }\end{array}$ & $\begin{array}{l}90.02^{\mathrm{a}} \\
\pm 0.03\end{array}$ & $\begin{array}{l}90.00^{\mathrm{a}} \\
\pm 0.01\end{array}$ & $\begin{array}{l}90.00^{\mathrm{a}} \\
\pm 0.03\end{array}$ & $\begin{array}{l}90.00^{\mathrm{a}} \\
\pm 0.02\end{array}$ & $\begin{array}{l}89.04^{\mathrm{b}} \\
\pm 0.01\end{array}$ & $\begin{array}{l}89.06^{\mathrm{b}} \\
\pm 0.05\end{array}$ & $\begin{array}{l}89.03^{\mathrm{b}} \\
\pm 0.03\end{array}$ & $\begin{array}{l}89.01^{\mathrm{b}} \\
\pm 0.06\end{array}$ & $\begin{array}{l}89.03^{\mathrm{b}} \\
\pm 0.01\end{array}$ & $\begin{array}{l}89.01^{\mathrm{b}} \\
\pm 0.05\end{array}$ \\
\hline 7 & ND & $\begin{array}{l}88.37^{\mathrm{a}} \\
\pm 0.04\end{array}$ & $\begin{array}{l}88.96^{\mathrm{a}} \\
\pm 0.06\end{array}$ & $\begin{array}{l}87.95^{\mathrm{b}} \\
\pm 0.07\end{array}$ & $\begin{array}{l}87.94^{\mathrm{b}} \\
\pm 0.05\end{array}$ & $\begin{array}{l}87.93^{\mathrm{b}} \\
\pm 0.07\end{array}$ & $\begin{array}{l}87.94^{\mathrm{b}} \\
\pm 0.06\end{array}$ & $\begin{array}{l}86.92^{\mathrm{c}} \\
\pm 0.03\end{array}$ & $\begin{array}{l}86.91^{\mathrm{c}} \\
\pm 0.02\end{array}$ & $\begin{array}{l}86.92^{\mathrm{c}} \\
\pm 0.05\end{array}$ \\
\hline 14 & ND & $\begin{array}{l}84.51^{\mathrm{a}} \\
\pm 0.04\end{array}$ & $\begin{array}{l}85.31^{\mathrm{a}} \\
\pm 0.06\end{array}$ & $\begin{array}{l}85.40^{\mathrm{a}} \\
\pm 0.03\end{array}$ & $\begin{array}{l}85.38^{\mathrm{a}} \\
\pm 0.05\end{array}$ & $\begin{array}{l}85.35^{\mathrm{a}} \\
\pm 0.07\end{array}$ & $\begin{array}{l}84.35^{\mathrm{b}} \\
\pm 0.05\end{array}$ & $\begin{array}{l}84.28^{\mathrm{b}} \\
\pm 0.08\end{array}$ & $\begin{array}{l}84.22^{\mathrm{b}} \\
\pm 0.04\end{array}$ & $\begin{array}{l}84.27^{\mathrm{b}} \\
\pm 0.03\end{array}$ \\
\hline 21 & ND & $\begin{array}{l}83.30^{\mathrm{c}} \\
\pm 0.08\end{array}$ & $\begin{array}{l}85.20^{\mathrm{a}} \\
\pm 0.07\end{array}$ & $\begin{array}{l}84.30^{\mathrm{b}} \\
\pm 0.03\end{array}$ & $\begin{array}{l}84.10^{\mathrm{b}} \\
\pm 0.04\end{array}$ & $\begin{array}{l}85.20^{\mathrm{a}} \\
\pm 0.02\end{array}$ & $\begin{array}{l}84.80^{\mathrm{b}} \\
\pm 0.09\end{array}$ & $\begin{array}{l}84.20^{\mathrm{b}} \\
\pm 0.04\end{array}$ & $\begin{array}{l}84.14^{\mathrm{b}} \\
\pm 0.02\end{array}$ & $\begin{array}{l}84.30^{\mathrm{b}} \\
\pm 0.03\end{array}$ \\
\hline
\end{tabular}

- ND: not determined - Values are mean of three replicates \pm SD - T1, T2 and T3: 1.5\% Carrageenan $+0.2 \%$ tangerine essential oil at 500, 1000 and $1500 \mathrm{rpm}$, respectively - T4, T5 and T6: 1.5\% Carrageenan $+0.4 \%$ tangerine essential oil at 500, 1000 and $1500 \mathrm{rpm}$, respectively - T7, T8 and T9: $1.5 \%$ Carrageenan $+0.6 \%$ tangerine essential oil at 500, 1000 and $1500 \mathrm{rpm}$, respectively

A lot of studies have been done to extend the mushroom preservation period. The use of essential oils become superior as an alternative to chemical preservatives and their use in foods meets consumers' demands for natural products (Alikhani-Koupae et al., 2014; Ding and Lee, 2019).

\section{Microbial status for mushroom samples during storage}

For approximately five days after harvesting the texture of mushrooms became tougher. This toughening was followed by a softening phase which might be related to the breakdown in the mushroom tissue caused by bacteria (Zivanovic et al., 2000).

\section{Assessment of antimicrobial activity of edible coating containing carrageenan and tangerine essential oil}

The obtained results in Table (7) showed that antimicrobial activity of the studied samples essential oils against Salmonella typhimurium and E. coli increased as the increase of essential oils concentration from 0.2 to $0.6 \%$ as well as increasing mixing speeds from 500 to $1500 \mathrm{rpm}$.

Aspergillus niger and Candida albicans not detected (ND) at $0.2 \%$ concentration of the essential oils at different mixing speeds. But, the essential oil concentrations intensified up to 0.4 and $0.6 \%$ with increasing mixing speeds up to $1500 \mathrm{rpm}$ caused an increase of inhibition zone against Aspergillus niger and Candida albicans.

These results are in agreement with Belletti et al. (2004) which reported that tangerine essential oil exhibited the highest antibacterial activity and it was effective against all the target bacterial species, especially against E. coil, S. typhii and Streptococcus sp.

Table (7): Antimicrobial activity of the edible coating containing carrageenan and tangerine essential oils (inhibition zone, $\mathrm{mm}$ )

\begin{tabular}{ccccc}
\hline \multirow{2}{*}{ Treatments } & $\begin{array}{c}\text { Salmonella } \\
\text { typhimurium }\end{array}$ & E. coli & $\begin{array}{c}\text { Aspergillus } \\
\text { niger }\end{array}$ & Candida albicans \\
\cline { 2 - 5 } & & Inhibition zone (mm) & ND \\
\hline T1 & 6 & 6 & ND & ND \\
T2 & 9 & 8 & ND & ND \\
T3 & 8 & 7 & ND & 7 \\
T4 & 9 & 6 & 9 & 8 \\
T5 & 13 & 11 & 7 & 9 \\
T6 & 11 & 9 & 8 & 11 \\
T7 & 11 & 12 & 10 & 16 \\
T8 & 14 & 13 & 9 &
\end{tabular}

ND: not detected - T1, T2 and T3: $1.5 \%$ Carrageenan $+0.2 \%$ tangerine essential oil at 500, 1000 and 1500 rpm, respectively

- T4, T5 and T6: $1.5 \%$ Carrageenan $+0.4 \%$ tangerine essential oil at 500, 1000 and $1500 \mathrm{rpm}$, respectively

- T7, T8 and T9: $1.5 \%$ Carrageenan $+0.6 \%$ tangerine essential oil at 500, 1000 and $1500 \mathrm{rpm}$, respectively 
Total bacterial and yeast and mold counts of mushrooms

Data in Table (8), showed the microbial evaluation of mushroom coated with tangerine essential oil at different concentrations $(0.2,0.4$ and $0.6 \%)$ and different mixing speeds (500, 1000 and $1500 \mathrm{rpm})$ compared with control. The results indicated that the highest values of total count of bacteria, yeast and mold of control sample achieved at all the different periods (zero time, after one and two weeks of storage time). The results revealed that the increase of tangerine essential oil concentration from 0.2 to $0.6 \%$ as well as raising mixing speeds from 500 to $1500 \mathrm{rpm}$ caused a decrease of total count of bacteria at zero time, after one and after two weeks of storage.

Similarly, total yeast and mold count markedly declined with increasing mixing speeds from 500 to $1500 \mathrm{rpm}$ and raising the concentration of tangerine essential oil (that used for coating of mushroom) from 0.2 to $0.6 \%$ at zero time, after one and after two weeks of storage.

These results are in agreement with Wang et al. (2008), they reported that citrus oil rich in flavonoids which can inhibit the growth of microorganisms.

Table (8): Effect of tangerine essential oil on total bacterial, yeast and mold count during storage time

\begin{tabular}{ccccccc}
\hline & \multicolumn{2}{c}{ Zero time } & \multicolumn{2}{c}{ After one week } & \multicolumn{2}{c}{ After two weeks } \\
\cline { 2 - 7 } Treatments & $\begin{array}{c}\text { Total } \\
\text { bacterial }\end{array}$ & $\begin{array}{c}\text { Yeast and } \\
\text { mold }\end{array}$ & $\begin{array}{c}\text { Total } \\
\text { bacterial }\end{array}$ & $\begin{array}{c}\text { Yeast and } \\
\text { mold }\end{array}$ & $\begin{array}{c}\text { Total } \\
\text { bacterial }\end{array}$ & $\begin{array}{c}\text { Yeast and } \\
\text { mold }\end{array}$ \\
\hline Control & $22 \times 10^{2}$ & $12 \times 10^{2}$ & $8 \times 10^{3}$ & $2 \times 10^{2}$ & $9 \times 10^{5}$ & $8 \times 10^{4}$ \\
T1 & $8 \times 10^{2}$ & $6 \times 10^{2}$ & $12 \times 10^{2}$ & $7 \times 10^{2}$ & $1 \times 10^{3}$ & $6 \times 10^{3}$ \\
T2 & $9 \times 10^{2}$ & $4 \times 10^{2}$ & $14 \times 10^{2}$ & $10 \times 10^{2}$ & $4 \times 10^{3}$ & $4 \times 10^{3}$ \\
T3 & $9 \times 10^{2}$ & $5 \times 10^{2}$ & $14 \times 10^{2}$ & $9 \times 10^{2}$ & $3 \times 10^{3}$ & $5 \times 10^{3}$ \\
T4 & $7 \times 10^{2}$ & $8 \times 10$ & $8 \times 10^{2}$ & $4 \times 10^{2}$ & $7 \times 10^{2}$ & $8 \times 10^{3}$ \\
T5 & $7 \times 10^{2}$ & $9 \times 10$ & $8 \times 10^{2}$ & $3 \times 10^{2}$ & $5 \times 10^{2}$ & $8 \times 10^{2}$ \\
T6 & $6 \times 10^{2}$ & $7 \times 10$ & $7 \times 10^{2}$ & $4 \times 10^{2}$ & $6 \times 10^{2}$ & $7 \times 10^{3}$ \\
T7 & $1 \times 10^{2}$ & $2 \times 10$ & $2 \times 10^{2}$ & $9 \times 10^{2}$ & $9 \times 10^{2}$ & $2 \times 10^{2}$ \\
T8 & $2 \times 10^{2}$ & $3 \times 10$ & $3 \times 10^{2}$ & $8 \times 10$ & $7 \times 10^{2}$ & $8 \times 10^{2}$
\end{tabular}

\section{CONCLUSION}

The effect of edible coating on physicochemical and microbiological properties of mushroom were studied using carrageenan incorporated with tangerine (Citrus reticulate) essential oils. Physicochemical properties of tangerine essential oils were specific gravity, refractive index, acid value and aldehyde were $0.853,1.4764,0.89 \mathrm{mg} \mathrm{KOH} / \mathrm{g}$ oil and $2.13 \%$, respectively. Antioxidant activity increased by increasing essential oil concentration. Nine components of tangerine essential oils were identified representing $100 \%$ of the total oil and the main component was Dlimonene $(80.55 \%)$. Rheological properties indicated that all samples exhibited non-Newtonian pseudoplastic behavior. Also, edible coating affects thickness, water vapor permeability of edible film, firmness, weight loss, moisture content, microbiological tests of coated mushroom samples.

\section{REFERENCES}

AACC (2010). Approved Method of the American Association of Cereal Chemists. Approved Methods the AACC Published by the American Association of Cereal Chemists. $13^{\text {th }}$ Ed. Inc. St. Paul, Minnesota, USA.
Alikhani-Koupae, M., M. Mazlumzadeh, M. Sharifan and M. Adibian (2014). Enhancing stability of essential oils by microencapsulation for preservation of button mushroom during postharvest. Food Science and Nutrition, 2: 526-533.

AOAC (2005). Official Methods of Analysis. Association of Official Analytical Chemists. $18^{\text {th }}$ ed., Washington, DC, USA.

Appendini, P. and J. H. Hotchkiss (2002). Review of antimicrobial food packaging. Innovative Food Science and Emerging Technologies, 3: 113126.

Ares, G., C. Lareo and P. Lema (2007). Modified atmosphere packaging for postharvest storage of mushrooms. a review. Journal of Fresh Produce, 1(1): 32-40.

Arnould-Taylor, W. E. (1981). Aroma therapy for the Whole Person. UK: Stanley Thornes 22-26.

ASTM (1996). Test methods for tensile properties of thin plastic sheeting, D882-91. Annual book of ASTM. Philadelphia, PA: American Society for Testing and Materials.

Belletti, N., M. Ndagijimana, C. Sisto, M. E. Guerzoni, R. Lanciotti and F. Gardini (2004). Evaluation of the antimicrobial activity of citrus essences 
on Saccharomyces cerevisiae. J. Agric. Food Chem., 52: 6932-6938.

Bhuyan, N., P. C. Barua, P. Kalita and A. Saikia (2015). Physico-chemical variation in peel oils of Khasi mandarin (Citrus reticulata Blanco) during ripening. Ind. J. Plant Physiol., 20(3): 227-231.

Boudries, H., S. Loupassaki, Y. LadjalEttoumi, S. Souagui, M. BachirBey, N. Nabet, A. Chikhoune, K. Madani and M. Chibane (2017). Chemical profile, antimicrobial and antioxidant activities of Citrus reticulate and Citrus clementina (L.) essential oils. International Food Research Journal, 24(4): 1782-1792.

Boughendjioua, H. and Z. Boughendjioua (2017). Chemical composition and biological activity of essential oil of mandarin (Citrus reticulata) cultivated in Algeria. Int. J. Pharm. Sci. Rev. Res., 44(1): 179-184.

Bourgou, S., F. Z. Rahali, I. Ourghemmi and M. S Tounsi (2012). Changes of Peel Essential Oil Composition of Four Tunisian Citrus during fruit maturation. The Scientific World Journal, Article ID 528593, doi:10.1100/2012/528593

Bozkurt, T., O. Gülnaz and Y. A. Kaçar (2017). Chemical composition of the essential oils from some citrus species and evaluation of the antimicrobial activity. Journal of Environmental Science, Toxicology and Food Technology, 11(10): 29-33.

Brand-Williams, B., E. M. Cuvelier and C. Benset (1995). Use of free radical method to evaluate antioxidant activity. Food Science and Technology, 28: 25-30.

Brennan, M., H. G.Le Port and T. R. Gormley (2000). Postharvest treatment with citric acid or hydrogen peroxide to extend the shelf life of fresh sliced mushrooms. Lebensmittel Wissenschaft and Technologies, 33: 285-289.

Brookfield Manual (1998). Brookfield Manual Operating Instruction. No. M/98-211-B0104. Brookfield Engineering Laboratories Inc., Middleborough.

Cagri, A., Z. Ustunol and E. T. Ryser (2004). Antimicrobial edible films and coatings. Journal of Food Protection, 67: 833-848.

Cha, D. S. and M. S Chinnan (2004). Biopolymer-based antimicrobial packaging: a review. Critical Reviews in Food Science and Nutrition, 44: 223-237.

Choi, H. S. (2010). Antioxidant activity in citrus essential oils flavor and fragrance. Published by John Wiley and Sons, Inc., Hoboken, New Jersey. P. 231.

Dang, K. T. (2008). Edible coatings influence fruit ripening, quality and aroma biosynthesis in mango fruit. Journal of Agricultural and Food Chemistry, 56(4): 1361-1370.

Dhall, R. K., E. Ayranci and S. Tunc (2013). Advances in edible coatings for fresh fruits and vegetables: A Review. Critical Reviews in Food Science and Nutrition, 53(5): 435-450.
Ding, P. and Y. L. Lee (2019). Use of essential oils for prolonging postharvest life of fresh fruits and vegetables. International Food Research Journal, 26(2): 363- 366.

Fan, S., J. Chang, Y. Zong, G. Hu and J. Jia (2018). GCMS Analysis of the composition of the essential oil from Dendranthema indicum var. Aromaticum using three extraction methods and two columns. Molecules, 23(3): 576-586.

FDA/BAM. (2001). Bacteriological analytical manual. Food and Drug Administration. Center for Food Safety and Applied Nutrition. Chapter 18, Yeasts, Molds and Mycotoxins, Gaithersburg, MD.

Fisher, K. and C. A. Phillips (2006). The effect of lemon, orange and bergamot essential oils and their components on the survival of Campylobacter jejuni, Escherichia coli $\mathrm{O} 157$, Listeria monocytogenes, Bacillus cereus and Staphylococcus aureus in vitro and in food systems. Journal of Applied Microbiology, 101(6): 1232-1240.

Fisher, K. and C. Phillips (2008). Potential antimicrobial uses of essential oils in food: is citrus the answer? Journal of Food Science and Technology, 19(3):156-64.

Ghasemnezhad, M., S. Zareh, M. Rassa and R. H. Sajedi (2013). Effect of chitosan coating on maintenance of aril quality, microbial population and PPO activity of pomegranate (Punica granatum L. cv. Tarom) at cold storage temperature. Journal of the Science of Food and Agriculture, 93: 368-374.

Guenther, E. S. (1948). The essential oils. (Vol. 1). New York: Van Nostrand Company Inc., London. Pp. 376-379.

Henriques, M. G., Santos A. Rodrigues, D. Gomes, C. Pereira1 and M. Gil (2013). Replacement of conventional cheese coatings by natural whey protein edible coatings with antimicrobial activity. Journal of Hygienic Engineering and Design, 34-47.

Javed, S., A. Javaid, S. Nawaz, M. K. Saeed, Z. Mahmood, S. Z.Siddiqui and R. Ahmad (2014). Phytochemistry, GC-MS Analysis, antioxidant and antimicrobial potential of essential oil from five citrus species. Journal of Agricultural Science, 6(3): 201-208.

Jiang, T., Q. Wang, S. Xu, M. M. Jahangir and T. Ying (2010). Structure and composition changes in the cell wall in relation to texture of shiitake mushrooms (Lentinula edodes) stored in modified atmosphere packaging. Journal of the Science of Food and Agriculture, 90(5): 742749. https://doi.org/10.1002/jsfa.3876

Lu, F. and L.Y. Foo (2001). Antioxidant activity of polyphenols from sage (Salvia officinalis). Food Chemistry, 75: 197-202.

Mahajan, P.V., F.A.R. Oliveira and I. Macedo (2008). Effect of temperature and humidity on the transpiration rate of the whole mushrooms. J Food Eng, 84: 281-288. 
Mahato, N., K. Sharma, R. Koteswararaob, M. Sinha, E. Baral and M. H. Cho (2019). Citrus essential oils: Extraction, authentication and application in food preservation. Critical Reviews in Food Science and Nutrition, 59(4): 611-625

Mohebbi, M., E. Ansarifar, N. Hasanpour and M. R. Amiryousefi (2012). Suitability of Aloe vera and gum tragacanth as edible coatings for extending the shelf life of button mushroom. Food and Bioprocess Technology, 5(8): 31933202.

Muriel-Galet, V. M. J., S. W. Cran, P. H. Bigger and R. Gavara, (2015). Antioxidant and antimicrobial properties of ethylene vinyl alcohol copolymer films based on the release of oregano essential oil and green tea extract components. Journal of Food Engineering, 149: 9-16.

Nguyen, P. M., L. P. Hang and N. T. Binh (2018). Effect of carrageenan as edible coating on storage of Manilkara zapota fruit. Journal of Global Pharma Technology, 10(7): 481-488.

Pelissari, F. M., M. V. E. Grossmann, F. Yamashita and E. A. Pineda (2009). Antimicrobial, mechanical, and barrier properties of cassava starch-chitosan films incorporated with oregano essential oil. Journal of Agricultural and Food Chemistry, 57:7499-7504.

Pereda, M., G. Amica and N. E. Marcovich (2012). Development and characterization of edible chitosan/olive oil emulsion films. Carbohydr. Polym., 87(2): 1318-25.

Rios, J. L. and M. C. Recio (2005). Medicinal plants and antimicrobial activity. Journal of Ethnopharmacology, 100: 80-84.

Saiful, J., S. Sitti and S. Salman (2013). Preparation and characterization edible film packaging from carrageenan. Proceedings of the 3rd Annual International Conference Syiah Kuala University (AIC Unsyiah), 3(3): 44-50.

Shamseldean, M. M. and E. G. Platzer (1989). Romanomermis culicivorax: Penetration of larval mosquitoes. Journal of Invertebrate Pathology, 54: 191-199.
Siah, W. M., A. Aminah and A. Ishak (2018). Effect of Cinnamomum zeylanicum essential oil on the physical and mechanical properties of edible films from kappaphycus alvarezii. Malays. Appl. Biol., 47(5): 197-203.

Silva, F. A. S. and C. A. V. Azevedo (2009). Principal Components Analysis in the Software AssistatStatistical Assistance. In: $7^{\text {th }}$ World Congress on Computers in Agriculture Conference Proceedings, 22-24 June 2009, Reno, Nevada (electronic only) 711P0409e. (doi:10.13031/2013.29066).

Singh, N., D. Vaidya, V. Mishra and K. S. Thakur (2016). Shelf life and storage quality of white button mushrooms (Agaricus bisporus) as affected by packaging material. Int. J. Adv. Res., 4(11): 1790-1799.

Singh, P., H. C. Langowski, A. A. Wani and S. Saengerlaub (2010). Recent advances in extending the shelf life of fresh Agaricus mushrooms: A review. Journal of the Science of Food and Agriculture, 90: 13931402.

Wang, Y. C., Y. C. Chuang and H. W. Hsu (2008). The flavonoid, carotenoid and pectin content in peels of citrus cultivated in Taiwan. Food Chem., 106(1): 277-284.

Wiset, L., N. Poomsa-ad and P. Jomlapeeratikul (2014). Effects of drying temperatures and glycerol concentrations on properties of edible film from konjac flour. Journal of Medical and Bioengineering, 3(3): 171-174.

Yang, S. A., S. K. Jeon, E. J. Lee, C. H. Shim and I. S. Lee (2010). Comparative study of the chemical composition and antioxidant activity of six essential oils and their components. Natural Product Research, 24:140-151.

Zivanovic, S., R.W. Buescher and K.S. Kim (2000). Textural changes in mushrooms (Agaricus bisporus) associated with tissue ultrastructure and composition. J. of Food Sci., 65(8): 14041408 . 
تأثير سرعة الدوران أثناء الخلط علي خصائص الغشاء القابل للأكل المحتوي علي الزيت العطري

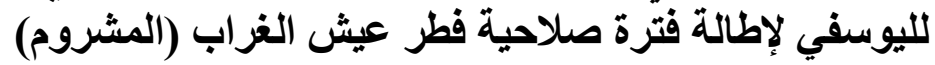

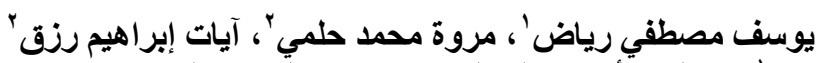

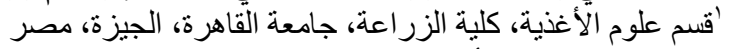

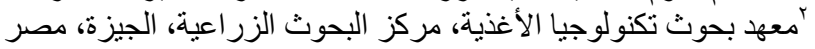

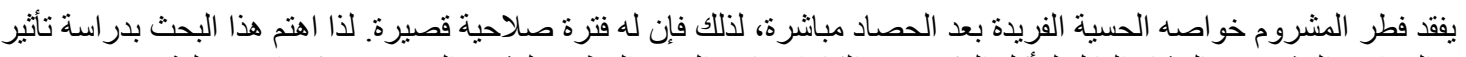

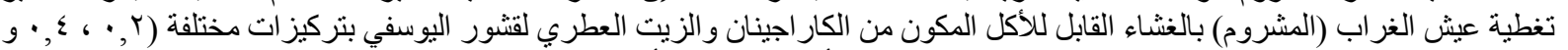

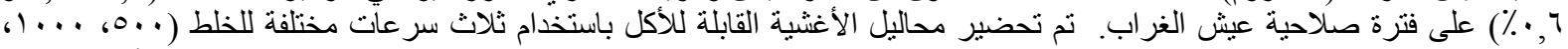

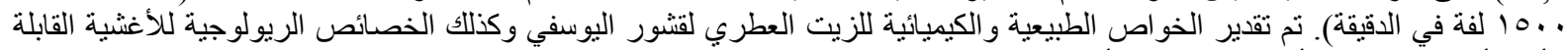

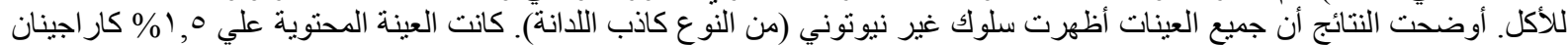

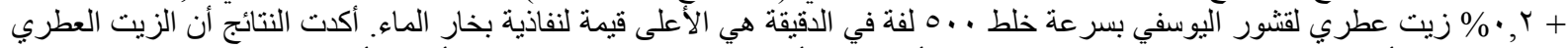

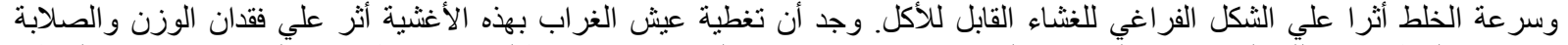

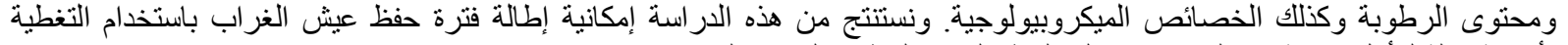

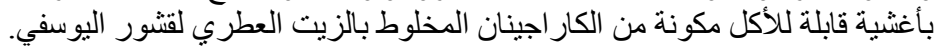

